\title{
BIRD MORTALITY AT RADIO AND TV TOWERS NEAR WINNIPEG, SEPTEMBER 1965
}

\author{
by Lawrie B. Smith, 335 Haney St., Winnipeg 20, Manitoba
}

Reports of bird mortality at radio and television towers in this region have been increasing since 1950 (Belcher, et al, 1966; Gollop, 1965; Lahrman, 1959, 1962, 1965; Nero, 1961, 1962; Velie, 1963); as more of these structures are being built each year it seems important to record observations on such collisions in order to learn what effect this has on bird populations. At the same time valuable information will be obtained on bird migration since the largest kills take place during the migration season, especially in the fall. These observations may also be useful in learning how to reduce the hazard posed to birds by these towers.

The tallest towers of this type in the Winnipeg, Manitoba area and their dates of erection are: CJAY TV tower at Ste. Agathe, about 23 miles south of Winnipeg, 1960; CFMW FM radio tower at $\mathrm{St}$. Norbert, about six miles south of Winnipeg, 1964; CBWT TV tower at Starbuck, about 10 miles west of Winnipeg, 1965 . The only published report of bird mortality at any of these towers to date is by Hosford (1962), who records 67 individuals of 25 species found on September 24, 1962 at CJAY TV tower. They were presumed to have collided with the tower and its supporting guy wires the previous night.

On three occasions in the latter part of September, 1965 similar kills were observed in the Winnipeg area. The results are of interest as they represent some of the largest kills reported to date for Manitoba and Saskatchewan as well. Since the three kills occurred within a week of each other it was also of interest to notice the change in species composition of the kills.

On the evening of September 22/23, migrating thrushes and warblers were heard passing over Winnipeg while a light drizzle was falling. On September 23, David Hatch, Bill Adams and myself visited the towers at Ste. Agathe, St. Norbert, and Starbuck. We arrived at the CJAY tower at 11:00 a.m. and finished at the CBWT tower at 5:30 p.m., having spent approximately one hour and 40 minutes at each of the TV towers and approximately 30 minutes at each of the radio towers. The area for 50 yards around CJAY tower was second growth hay and scattered clumps of alfalfa with a field of oats on the south side and a field of swathed wheat on the north side; the four towers at CKY were in a line running. north and south and had tall weeds immediately under them, swathed wheat on the east side and second growth hay on the west side; the CFMW tower had stubble on the west and north sides, a gravel parking lot on the south side and the lawns of the transmitter building on the east side; the area surrounding the $\mathrm{CBWT}$ tower was fallow in ridges 10 inches high left by ducktooth harrows.

At the end of the day we had collected 184 dead or injured birds of 35 species (Table 1). The number of birds found decreased as the height of the tower became less. This supports previous observations that the largest kills occur at towers 500 feet high and over (Janssen, 1963). Most of the birds were found on the south or east side of the towers or near the supporting cables on the north side.

On September 29 I received a message from Don Dennix, the maintenance engineer at CJAY TV, that there had been a substantial kill of birds at the tower sometime between his visit on the morning of September 27 and the morning of September 29. Dr. Ralph Bird and I arrived at the tower at about 1:30 p.m. and spent one hour picking up dead birds before a steadily increasing drizzle forced us to stop. Dennis had collected about 30 birds around the building. Most of the birds we found were within 50 yards of the 
south and east sides of the tower near the northwest set of supporting cables. Although Dennis could not say on which night the birds had been killed, it seemed from their relatively fresh appearance and the absence of predation on corpses that they had been killed on the evening of September $28 / 29$. A summary of the birds we found is given in Table 2 .

On the morning of October 1, I received a second call from Dennis to say that there had been another kill at the CJAY TV tower. I arrived at the tower at approximately noon and spent $1 \frac{1 / 2}{2}$ hours collecting dead birds, mostly south and east of the tower and a few on the southwest side. Again, Dennis had already collected about 30 specimens around the building. On this date many of the birds were partly eaten or there was only a mass of feathers on the ground where the body had been, suggesting that the kill had taken place on the evening of September 29/30 rather than the evening of September $30 /$ October 1. Dennis had not been to the tower between the morning of September 29 and the morning of October 1 and therefore, could not say on which night the kill had occurred. Although the ground had been searched fairly thoroughly in the first two visits to the CJAY tower, time did not permit such a thorough search on October 1 and perhaps as many, or more, were not found. Thus, the kill on that date was by far the largest of the three recorded at that tower in 1965 (see Table 2).

Since weather conditions seem to be an important factor in these kills, it would be pertinent to record such details as the passage of cold fronts as indicated by temperature changes and wind shifts, as well as cloud conditions and duration of precipitation, if any, on the night of a kill. Accordingly, the following weather data have been taken from the monthly summary of records made by the Meteorological Branch of the Department of Transport of Canada at the Winnipeg International Airport.

September 22 was cool and cloudy all day, the highest temperature being $55^{\circ} \mathrm{F}$. ; it dropped from $55^{\circ} \mathrm{F}$. at $3: 00$ p.m. to $47^{\circ} \mathrm{F}$. at $4: 00 \mathrm{p.m}$.; the lowest temperature during the night, $43^{\circ} \mathrm{F}$., lasted from 4 until 6:00 a.m. on September 23. The wind changed from SE 6 at 9:00 a.m. to N 16 at 2:00 p.m., decreased to $\mathrm{N} 8$ by midnight and then increased to NW 13 by 8:00 a.m. on September 23. There were light showers in the afternoon and evening that amounted to 0.27 inches of rainfall. On September 28 it remained cool with a high of $46^{\circ} \mathrm{F}$. at noon; the temperature dropped from 41 to $35^{\circ} \mathrm{F}$. between $8: 00$ and 9:00 p.m., was $32^{\circ} \mathrm{F}$. from midnight to $1: 00$ a.m. and then rose steadily to $42^{\circ} \mathrm{F}$. by $8: 00$ a.m. The winds were N 4-6 m.p.h. in the afternoon and became lighter after midnight. There was no precipitation. The weather remained cool and cloudy all day on September 29th, the high being $45^{\circ} \mathrm{F}$. at noon. The temperature gradually dropped during the night until a drop from 38 to $33^{\circ} \mathrm{F}$. occurred between $3: 00$ and 4:00 a.m. on September 30 . The winds were $\mathrm{N} 10$ in the middle of the day on September 29 and gradually decreased to $\mathrm{N} 8$ at 8:00 p.m. and then changed to $\mathrm{NW} 6$; this was maintained until 8:00 a.m. on September 30 when the wind strengthened until it reached NW 20 at $3: 00$ p.m. From 1:00 p.m. September 29 until $1: 28$ a.m. September 30 a total of 0.29 inches of rain fell.

The weather throughout September had been generally cool and wet, in fact, it was the coolest September on record at Winnipeg. The cool, wet weather began in the last week of August and was steady enough to halt harvesting operations in the area until October. Rainfall for September was above normal and sunshine was below normal. Record low temperatures were experienced for two dates during the month, $19.8^{\circ} \mathrm{F}$. on the $25 \mathrm{th}$ and $18.9^{\circ} \mathrm{F}$. on the $26 \mathrm{th}$.

The wet weather during the month may have delayed the migration of many birds until they were forced to migrate by the strong cold front that began to move southward on September 21 and led to the very low temperature recorded on the 25 th and 
26th. The birds that were killed on the night of September 29 may have begun their flight under dry conditions but ran into precipitation where the cold air met the advancing warm air moving in from the south. It has been suggested that once birds begin migrating they are unable to stop if they run into unfavourable weather conditions (Williams, 1950).

The interesting feature about these kills is the change in species composition as the season advanced. The first kill was composed predominantly of warblers and sparrows that are normally found in large numbers around Sparrow and Swamp Sparrow are all the first week in September in Win- nipeg during fall migration. For example, Tennessee Warbler, Oyenbird, Yellowthroat, American Redstart, Savannah Sparrow, Lincoln's thought to leave Manitoba between mid-August and mid-September. The species composition in the second kill did not differ greatly from the first except for the absence of Red-eyed Vireo, Philadelphia Vireo, American Redstart or Savannah Sparrow, although there were great numbers of Myrtle and Orange-crowned warblers. The greatest difference was between the kill on September 28 and the kill on September 29; the number of Swainson's Thrush and Gray-cheeked Thrush increased greatly, and two

TABLE 1

Dead birds found September 23, 1965 at TV and Radio towers near Winnipeg, Manitoba

SPECIES

TV RADIO

TOWERS TOWERS

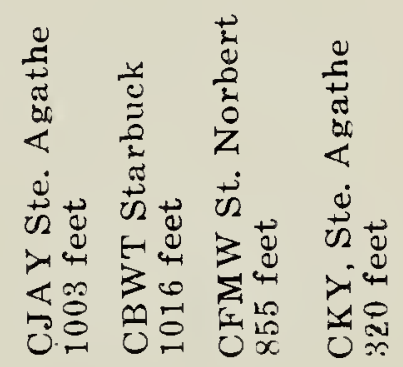

Yellow-bellied

Sapsucker

Long-billed Marsh

Wren

Short-billed Marsh

Wren

Catbird

Swainson's Thrush...

Gray-cheeked Thrush

Solitary Vireo

Red-eyed Vireo

Philadelphia Vireo

Black-and-White

Warbler

Tennessee Warbler

Orange-crowned

Warbler

Yellow Warbler

Magnolia Warbler.

Cape May Warbler..

Myrtle Warbler

Chestnut-sided

Warbler

Bay-breasted

Warbler

Blackpoll Warbler...

1
SPECIES

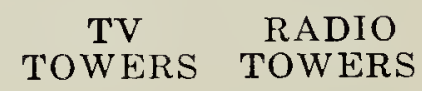

Palm Warbler

Ovenbird TOWERS TOWERS

Northern Water-

thrush

Mourning Warbler...

Yellowthroat

American Redstart.

Savannah Sparrow.

Baird's Sparrow

Sharp-tailed

Sparrow

Clay-colored

Sparrow

Harris' Sparrow

White-crowned

Sparrow

White-throated

Sparrow

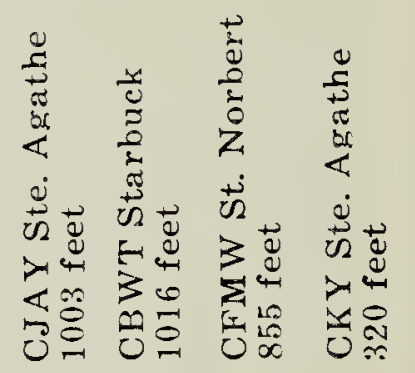

Lincoln's Sparrow... 9

Swamp Sparrow ..... 6

Lapland Longspur.

Total

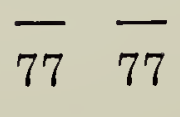

35 species; 184 individuals 
species known to migrate normally at that time of year, Hermit Thrush and Slate-colored Junco, were found in the collections for the first time. The peak of the thrush migration through southern Manitoba is thought to occur in the first ten days of September but it now appears that large numbers are present until the third week, or even the end of September.

In 1962 three species were found that were not found in 1965 - Wood Pewee, Nashville Warbler and Canada Warbler, whereas eight species were found in 1965 that were not found in 1962 - Catbird, Philadelphia Vireo, Cape May Warbler, Chestnut-sided Warbler, Sharp-tailed Sparrow, Claycolored Sparrow, Harris' Sparrow and Lincoln's Sparrow. While it is difficult to compare the kills in the two years, it may be worth noting that the most numerous species found in 1962 were the Myrtle Warbler (13) and the Blackpoll Warbler (8). These species were not numerous in the first kill recorded in 1965 , but were more numerous in the second and third kills. This suggests that the fall migration through southern Manitoba was somewhat later in 1965 than in 1962.

It would be interesting to compare the kills recorded at Winnipeg with kills recorded in neighboring regions such as Saskatchewan and Minnesota, but since many more kills have been documented from these regions than from the Winnipeg area to date, it does not seem that a detailed comparison of the numbers and species is warranted at this time. Still, from the information now available it does seem that the large kills recorded at TV towers in Saskatchewan occur earlier in the fall migration than those recorded near Winnipeg. The recorded kills containing more than 50 individuals in Saskatchewan have occurred August 20/21, 1964 (Gollop, 1965; Lahrman, 1965), September 2/3, 1962 (Nero, 1961), September 3/4, 1964 (Gollop, 1965 ; Lahrman, 1965), September 7, 1962 (Lahrman, 1962), September 9/10 (Nero, 1961). The kills recorded in the Winnipeg area have occurred towards the end of September, the time of year that some large kills have been recorded in Minnesota (Feehan, 1963; Green, 1963; Janssen, 1963; Peterson, 1963), and in Wisconsin (Kemper, 1959). It would be very interesting in the future to be able to compare the kills recorded in many different places dur-

TABLE 2

Dead birds found September 29, 1965, and October 1, 1965 at CJAY TV Tower at Ste. Agathe, Manitoba SPECIES

Sora

Common Snipe SEPT. 29 OCT. 1

Yellow-bellied

Sapsucker

$2 \quad 1$

House Wren

Hermit Thrush

Swainson's Thrush

Gray-cheeked Thrush

Ruby-crowned

Kinglet

Red-eyed Vireo

1

2

Philadelphia Vireo.

Tennessee Warbler

Orange-crowned

Warbler

Magnolia Warbler.

Myrtle Warbler

Bay-breasted

Warbler

Blackpoll Warbler

Palm Warbler

Ovenbird

Northern Water-

thrush

Connecticut

Warbler

Mourning

Warbler

Yellowthroat

American Redstart

Savannah Sparrow.

Slate-colored Junco.

Clay-colored

Sparrow

Harris' Sparrow.

White-throated

Sparrow

10

Fox Sparrow

Lincoln's Sparrow....

Swamp Sparrow 
ing the same fall migration to determine whether the pattern of migration of some of the thrushes, vireos, warblers and sparrows is the same as the pattern thought to occur on the basis of visual observations. As Nero (1961) points out, not only do poor weather conditions for migration have to be present to produce a kill at tall towers, but large numbers of birds must be migrating at the same time.

I am very grateful for the assistance of those people mentioned in the report who helped collect and identify the specimens found at the various towers and also to David R. M. Hatch and Harold V. Hosford for providing literature related to this subject.

\section{LITERATURE CITED}

Belcher, Margaret, A. Binnie, and Betty Binnie. 1966. The 1965 fall warbler migration at Regina. Blue Jay, $24: 10$.

Feehan, J. 1963. Destruction of birdlife in Minnesota-Sept. 1963. II. Birds killed at the Ostrander television tower. Flicker, 35: 111.
Green, Janet C. 1963. Destruction of birdlife in Minnesota - Sept. 1963. III. Notes on kills at Duluth on September 18/19. Flicker, $35: 112$.

Gollop, M. A. 1965. Bird migration collision casualties at Saskatoon. Blue Jay, 23:15.

Hosford, H. V. 1962. Migrant bird casualties at TV towers. Natural History Society of Manitoba. Ornithology Section Newsletter No. 1. Summer: 5. Mimeo.

Janssen, R. B. 1963 a. Destruction of birdlife in Minncsota - Sept. 1963. I. Birds killed at the Lewisville television tower. Flicker, $35: 110$.

Janssen, R. B. 1963b. Destruction of birdlife in Minnesota - Sept. 1963. V. Television towers in Minnesota. Flicker, $35: 113$.

Kemper, C. A. 1959. More TV tower destruction. Passenger Pigeon, $21: 135$.

Lahrman, F. W. 1959. TV tower casualty list. Blue Jay, $17: 142$.

Lahrman, F. [W.] 1962. Fall migration TV tower kills, 1962 . Blue Jay, $20: 152$.

Lahrman, F. W. 1965. Regina and Lumsden TV tower bird mortalities, 1964. Blue Jay, $23: 18$.

Nero, R. W. 1961. Regina TV tower bird mortalities - 1961. Blue Jay, $19: 160$.

Nero, R. W. 1962. Regina TV tower mortality, May 11-12, 1962. Blue Jay, $20: 151$.

Peterson, Mrs. A. W. 1963. Destruction of birdlife in Minnesota - Sept. 1963. IV. Birds killed at Park Rapids. Flicker, 35:113.

Velie, Elizabeth D. 1963. Report of a survey of bird casualties at television towers, ceilometers, and other obstructions. Flicker, $35: 79$.

Williams, G. G. 1950. Weather and spring migration. Auk, $67: 52$.

\section{SIXTH ANNUAL MAY BIRD CENSUS, REGINA}

The concerted efforts of 41 people in six parties resulted in the tallying of 144 species of birds (with an estimated total of 21916 individual birds seen) in Regina's annual May Bird Census, May 15, 1966, in an area constituting a circle of 30 -miles diameter around the city of Regina. Apart from the comparative picture of spring migration that this yearly count gives, it is considered by the sponsoring Regina Natural History Society to be worthwhile as a social and educational activity of the club. Any interested members of the Society are invited to participate, and this brings many who can join the party for only part of the day, and some who are relatively inexperienced bird watchers. Many of the latter, after scouring the country for all or part of the long (6:00 a.m. to dusk) day with avid "listers", are able to say that they saw a bird for the first time.
The 1966 spring migration at Regina followed a rather curious pattern: some of the first migrants arrived very early, but an unusually cold April slowed down later movements. A 48-hour snow storm (April 26-27) brought nine inches of snow, and the last five days of the month had freezing temperatures. The delayed migration is reflected in the May count. One conspicuous example is the large number of Harris' Sparrows (251) which have usually reached a peak earlier. The fact that 35 Loggerhead Shrikes were seen (compare 16 on May 15, 1965) also suggests a belated migration, for in most of the Regina area breeding shrikes are not especially common. The rather large total of 10 Sparrow Hawks (compare 1 seen May 15, 1965) may have a similar explanation, although the presence of a pair at a location where they were known to nest in 